\title{
COVID-19 Pandemic/Lockdown and Its Impact on Sustainable Access to Safe Water in the Developing World: A Case Study
}

\author{
T.O. Ogunbode ${ }^{1 *}$, Y.T. Nejo ${ }^{2}$, O.J. Kehinde ${ }^{3}$
}

${ }^{1}$ College of Agriculture, Engineering and Science, Environmental

Management and Crop Production Unit, Bowen University, Iwo, NIGERIA

${ }^{2}$ College of Agriculture, Engineering and Science, Microbiology Programme, Bowen University, Iwo, NIGERIA

${ }^{3}$ Department of Estate Management, Lead City University, Ibadan, NIGERIA

* Corresponding author:

timothy.ogunbode@bowen.edu.ng

\begin{abstract}
COVID-19 pandemic has impacted on the global socio-economic spectrum, including water accessibility especially in developing countries. The global achievement in water access subsector at the end of MDGS could be jeopardized with the unabated prevalence of a novel and contagious disease which knows no bound. With the pandemic and its spreading mode through close contact which brought about the total lockdown of the global community, accessibility to improved water could have been restricted. To assess the impact of the disease/lockdown on water access, a survey was conducted during the lockdownfree days across randomly selected inhabitants of Iwo, Osun State, Nigeria. Data analysis was descriptive. The results revealed that the disease/lockdown restricted the movement of the respondents to search for potable water. Respondents adopted various strategies to ensure water availability in their homes including night fetching $(12.2 \%)$, rotation $(16.2 \%)$, purchase $(1.4 \%)$, surface sources $(8.8 \%)$ among others. About $78.3 \%$ either agreed or strongly agreed that the pandemic had pronounced impacts on domestic water supply and subjected them to untold hardship searching for water while trying to avoid physical contact. This work, therefore recommends review of global target on water access to ensure each house is connected to safe and sustainable water sources.
\end{abstract}

Keywords: water access, COVID-19, developing nations, sustainable development goals, lockdown, Nigeria, pandemic, Iwo, Osun State, sustainable

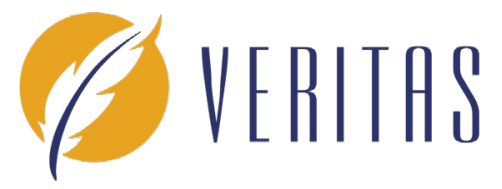

\section{EUROPEAN JOURNAL OF BASIC MEDICAL SCIENCE}

Eur J Basic Med Sci 2021;11(1):8-17

Received: 14 Nov 2020

Accepted: 14 Dec 2020 


\section{INTRODUCTION}

The global achievement in water access subsector at the end of MDGS could be jeopardized with unabated prevalence of a novel and highly contagious disease which knows no boundary. United Nations [1,2] had reported that a remarkable improvement had been recorded in the global pursuit of water access, including developing nations, at the end of 2015 deadline of Millennium Development Goals (MDGs), with $91 \%$ access higher than $76 \%$ in 1990. Many homes are able to access improved water for use, though there are variations in the accessibility across nations, especially in developing countries. However, in view of the ravaging COVID-19 across the globe, there is likelihood that the accessibility to potable water could be endangered most in these regions. For instance, with the prevalence of the disease which has claimed millions of life and other millions having being tested positive globally, the movement of people in search of potable water has become a serious challenge, as water points are mostly shared in the underdeveloped world [3,4]. Ainuson [5] reported that $58.8 \%$ and $50 \%$ shared water points in Ghana and South Africa respectively. Though, a measure of progress in water access was attained in Nigeria in 2015 , clinching to about $69 \%$, the country still lag behind other countries in sub-Saharan region [6-8]. For instance the country has regressed in access to piped water service on premise in urban areas as it dropped from three in every ten persons in 1990 to even less than one in 2015, the decrease that was attributed to rapid urbanization, lack of investment and institutional constraints in the expansion service [6]. Also, in order to curtail poor access to water during the COVID-19 crisis, some African countries like Ghana, Kenya and the Democratic Republic of Congo (DRC) had to announce various forms of free water in the affected areas [9].

Barely four years after the completion of MDGs in 2015, COVID-19, first discovered in December, 2019 in Wuhan, China, and having hit many countries in the world has claimed many lives globally. As at 10th July, 2020, WHO [10] report shows a total of $12,387,828$ confirmed cases and 557,405 reported deaths globally, and still counting. As the disease becomes rampaging, quite a number of African countries were infected with the diseases so far, with an approved cure and/or vaccine yet to be developed globally. The disease COVID-19, an acronym for Corona Virus Disease discovered in 2019 is caused by a virus called Severe Acute Respiratory Syndrome Coronavirus 2 (SARS-CoV-
2) which is mostly contracted through close contact with infected person. According to WHO [10], the symptoms of the disease are categorized into most common symptoms which are fever, dry cough, and tiredness, less common symptoms which may affect some people and these include aches and pains, nasal congestion, headache, conjunctivitis, sore throat, diarrhea, loss of taste or smell, a rash on skin or discoloration of fingers or toes and lastly, symptom that are peculiar with older people and those with underlying chronic medical problems like high blood pressure, diabetes, or cancer, and these individual are at higher risk of developing serious illness such as difficulty breathing, severe pneumonia or septic shock. Several infected countries had to restrict movement of their people in order to curtail the spread of the disease. Thus, institutions of learning, industries, worship places, markets and other places that attract groups of people at a time were practically locked down. In addition, travelling across borders were halted, social gatherings were suspended. All measures to curtail the highly contagious disease were put in place, even, to the level that every global citizen was restricted to their respective homes.

Developing nations were not excluded from this pandemic as countries in the region were equally locked down; interstate travelling was suspended, worship services in churches and mosques were closed down, markets shut down and all social gatherings and clubs were all suspended as at the time this investigation was being carried out. As at 10th July, 2020, Nigeria has recorded 30,789 confirmed cases of COVID-19 with 689 reported deaths [11]. According to WHO (2020), COVID19 is highly contagious and can easily be contracted through contact with infected individuals. The disease spreads primarily from person to person through small droplets expelled from the nose or mouth when a person with COVID-19 coughs, sneezes, or speaks. These droplets are relatively heavy, do not travel far and quickly land on objects and surfaces around the person such as tables, doorknobs and handrails. People can therefore be infected with the virus by direct contact with infected person or by touching contaminated surfaces or objects, then touching their eyes, nose or mouth. Thus, according to WHO, it is important to stay (at least 1 meter) away from others.

However, despite successes achieved globally towards water accessibility, UNU-INWEH [12] stated that about 663 million people still lack access to improved water sources. Most African countries, according to Africa 
Table 1. Combined Global and African Ranking- 8 Country Populations with the Least Sustainable Access to Improved/Clean Water Sources

\begin{tabular}{cccc}
\hline $\begin{array}{c}\text { Global ranking by country with least sustainable } \\
\text { access to improved drinking water source }\end{array}$ & Name of Country & $\begin{array}{c}\text { Country } \\
\text { Population }\end{array}$ & $\begin{array}{c}\text { \% of population without } \\
\text { improved drinking water sources }\end{array}$ \\
\hline $1^{\text {st }}$ & Somalia & $9,133,000$ & $70 \%$ \\
\hline $2^{\text {nd }}$ & Ethiopia & $82,825,000$ & $62 \%$ \\
\hline $3^{\text {rd }}$ & Madagascar & $19,625,000$ & $59 \%$ \\
\hline $4^{\text {th }}$ & Papua New Guinea & $6,732,000$ & $59 \%$ \\
\hline $11^{\text {th }}$ & Chad & $11,206,000$ & $50 \%$ \\
\hline $17^{\text {th }}$ & Nigeria & $154,729,000$ & $42 \%$ \\
\hline $19^{\text {th }}$ & Togo & $6,619,000$ & $40 \%$ \\
\hline $24^{\text {th }}$ & Yemen & $23,580,000$ & \\
\hline
\end{tabular}

Source: Culled from Africa Public Health Info (Downloaded on 16 June 2020)
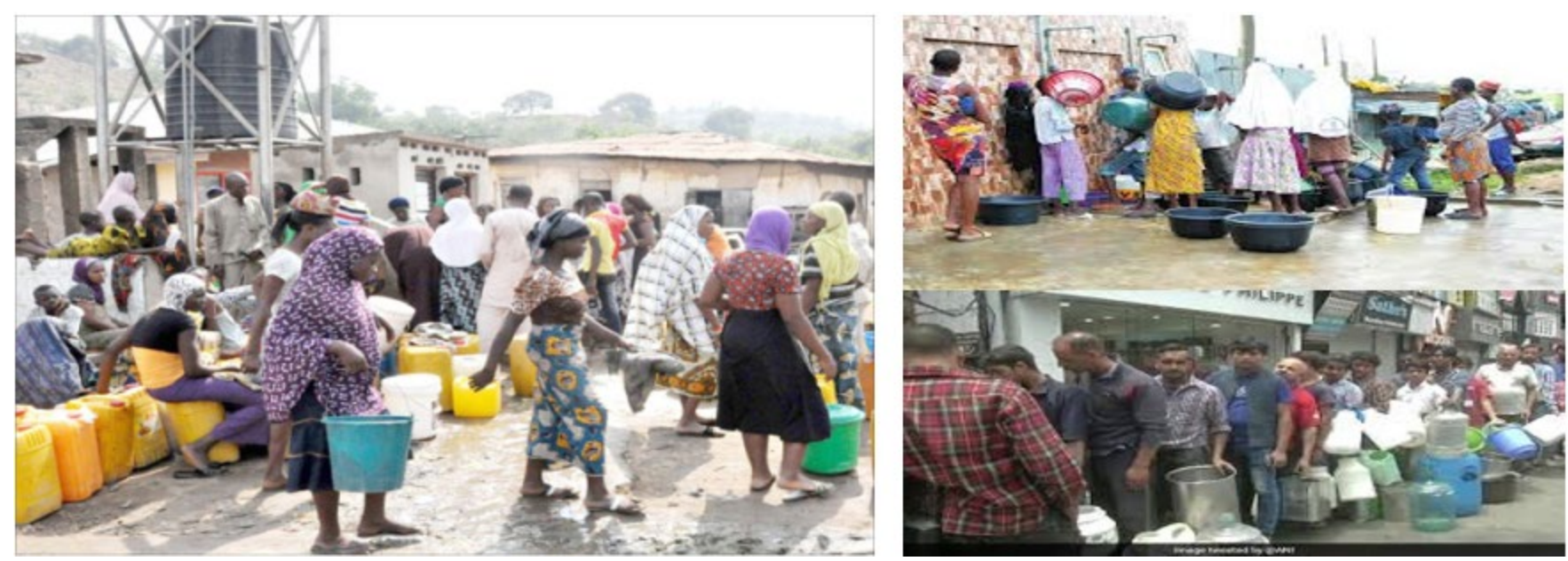

Figure 1. Situations of water searching/sharing in some locations in developing nations

(Source: Google image)

Public Health Info and WHO, are still lagging behind in providing safe water for domestic uses for their teeming population. Population with the least sustainable access to improved drinking water source as shown in Table 1 include Somalia, 70\%; Madagascar, 59\%; Chad, $50 \%$, Nigeria, $42 \%$ and Togo with $40 \%$. The five countries were ranked $1 \mathrm{st}, 3 \mathrm{rd}, 11 \mathrm{th}, 17 \mathrm{th}$ and 19 th respectively, both globally and in Africa. Yemen access to improved water is one of the least access globally with $38 \%$.

It was further reported that the proportion of access to pipe-borne water network within the premises of houses is just $35 \%$ for urban centres while in the rural areas, the proportion is abysmally low, just $5 \%$. The implication of this is that most homes have to travel in search of water out of their premises. Such sources include boreholes, dug-out wells, surface sources such as streams, brooks and rivers, dams, canals, irrigation channels, tanker trucks, unprotected springs and even bottled water, all of which WHO categorized as unimproved water sources. Though, it has not been established if the virus could be contracted from water,
Mallapaty [14], Rilmoldi et al. [15], and Wurtzer et al. [16] in their separate studies in Netherlands, Italy and Paris respectively established the presence of SARSCoV-2 in waste water and even surviving for up to eight days. If this could be, developing countries may be seriously infected as most of their inhabitants, especially their rural communities rely on surface and other untreated water sources for home use, which Ogunbode et al. [17] reported to be more susceptible to pollutants. Many of these sources are often crowded with people with their containers of different sizes. Thus, there are long queues and at times, fighting at water points which make social distancing to prevent the infection unachievable.

However, with the ravaging of contagious COVID-19 and the associated lockdown put in place by the governments globally, Nigeria inclusive, it is expected that the poor access to potable water may still become deteriorated, if the directive on lockdown by the government will be effectively implemented, otherwise, the situation of COVID-19 spread may be 


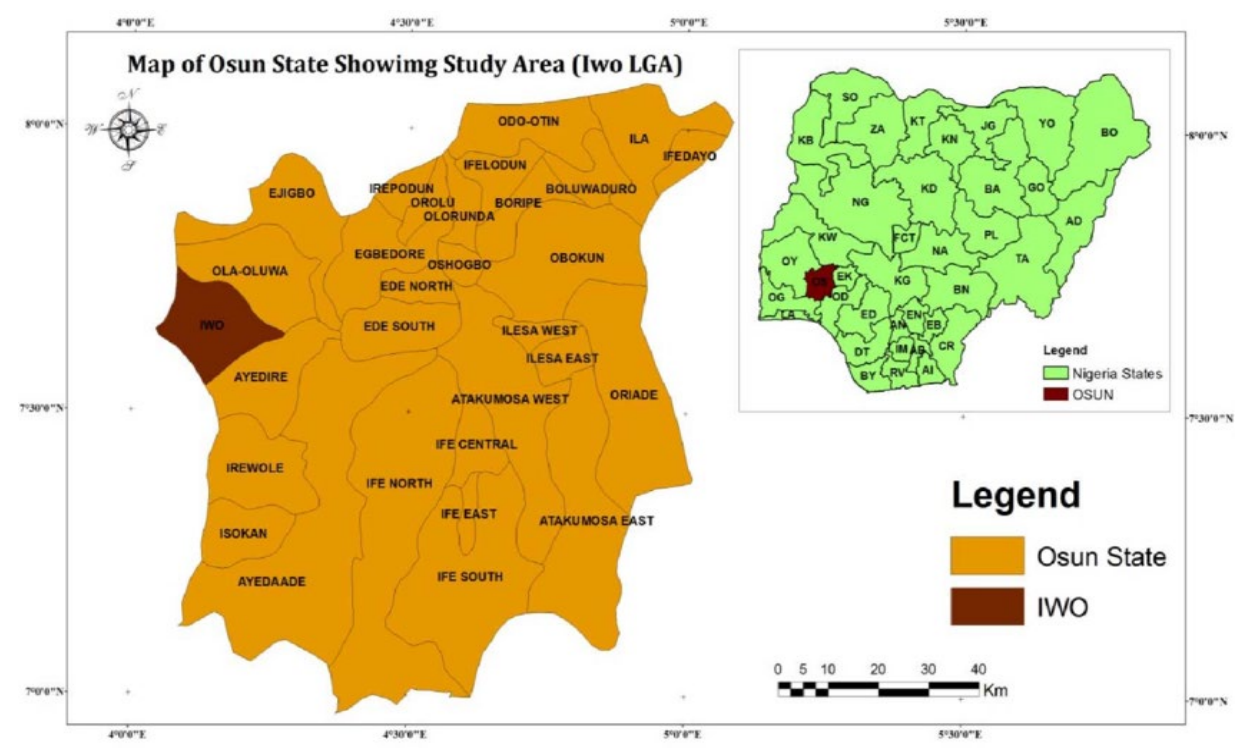

Figure 2. Iwo in Osun State Context (Inset: Map of Nigeria showing Osun State) Source: Google image

worsened. The situation during the lockdown in water access sub-sector is still expected to prevail even after the lockdown (post-COVID-19) since social distancing forms one of the most important measures to avoid being infected with the virus.

The major source of water to most households in urban centres in Nigeria, including Iwo in Osun State, is underground [17-19]. Though, Aiba Water Reservoir located within Iwo township was established to provide potable water to the inhabitants, this has not yielded positively for many reasons, including maintenance problems. Only few homes within a few meters to the dam are connected to the piped water service and the supply from it is even grossly erratic. In view of these scenarios, many of Iwo inhabitants have resorted to ground water resource for their domestic use. This is obtained from dug-out wells, deep boreholes and motorized boreholes which are either provided by each household, religious organizations, philanthropists and the government, especially, at State and Local level. This is in addition to the prevailing tropical climatic condition which is characterized by eight months of rainfall (March to October). It is important to note that water points in the town are either privately owned or shared among homes. However, there are still evidences of water crisis in the town such as long queues and at times, fighting at water points, night fetching, and long trekking among others. However, there has been no official report of any person infected with COVID-19 in Iwo and presently, there is no single isolation centre in the town, though it was also covered by both Federal and State governments' directive on lockdown.

It is in view of these that this study aimed at assessing the implications of COVID-19 and lockdown directives on accessibility to potable water in Iwo Local Government area (LGA) of Osun state, Nigeria. Specific objectives are to assess the implications of COVID-19 disease and its associated lockdown on households' access to potable water supply; and also to examine the strategies adopted by households to access potable water in view of the global lockdown.

\section{RESEARCH METHODOLOGY}

\section{The Study Area}

This study was carried out in Iwo Township, the administrative headquarters of Iwo Local Government Area (LGA) in Osun State, Southwestern Nigeria. The town (see Figure 1) is located on geographical coordinates $7^{0} 38^{\prime} \mathrm{N}$ and $4^{0} 11^{\prime} \mathrm{E}$ and has an approximate land area of $245 \mathrm{~km}^{2}$. The National Population Commission [20] puts the population of Iwo at 191,348 people with an annual growth rate of $2.6 \%$. The population of the town ten years after was 223,206 people and by 2018 , it has risen to 262,817 people. Apart from the natural growth, the population of Iwo has witnessed significant increase as a result of the establishment of Bowen University in 2002 and the popular periodic Odo-Ori Market which continues to be patronized by people from nearby cities and the rural suburbs apart from encouraging new settlers in the 
Table 2. Gender Distribution of the Respondents

\begin{tabular}{ccc}
\hline & & \\
\hline Female & 126 & 85.1 \\
\hline Male & 22 & 14.9 \\
\hline Total & 148 & 100.0 \\
\hline
\end{tabular}

Source: Authors' fieldwork, 2020

town. Also, by the time the proposed Federal College of Education in Osun State to be sited in Iwo town fully commence, the town may witness further population increase. Iwo is located within the tropical climate which is characterized by seasonal rainfall and mean monthly temperature of about $28^{\circ} \mathrm{C}$.

\section{Data Sources and Analysis}

This study was carried out through a survey. One hundred and fifty households were randomly selected for the administration of questionnaire in the study area. However, one hundred and forty eight copies of the questionnaire were retrieved. The survey was carried out during the days the lockdown was partially lifted (Thursday to Sunday weekly) by the Osun State government, and with the assistance of field assistants, who were adequately trained on the administration of the survey. Female head of households were the target population consequent upon the cultural belief that they hold more responsibility in providing water for households' domestic activities. In the absence of the female head, any other adult female or male was interviewed. The study made most of descriptive statistics for analysis.

\section{RESULTS AND DISCUSSION}

\section{Socioeconomic Attributes of Respondents}

The study evaluated the socioeconomic attributes of households that were presumed to have bearing on water accessibility in the study area. The attributes include: gender, educational qualification and monthly income. Results of findings are discussed as follows:

\section{Gender Distribution of the Respondents}

The results of the study show that there were more females $(85.1 \%)$ than males (14.9\%) (see Table 1$)$. Thus, a higher proportion of females were involved in the survey. The male respondents have been involved where female head of the households indisposed. The study, in consonance with other studies considered the significance of female gender in water supply in the developing nations [21-26].
Table 3. Educational Qualifications of Respondents

\begin{tabular}{ccc}
\hline Level of Education & No of Responses & $\%$ \\
\hline No Formal & 20 & 13.5 \\
\hline Primary & 86 & 58.1 \\
\hline Secondary & 33 & 22.3 \\
\hline Tertiary & 09 & 6.1 \\
\hline Total & 148 & 100.0
\end{tabular}

Source: Authors' fieldwork, 2020

Table 4. Income Distribution of the Respondents

\begin{tabular}{ccc}
\hline $\begin{array}{c}\text { Income Category (\# per } \\
\text { month) }\end{array}$ & No of Responses & $\%$ \\
\hline$<2000$ & 15 & 10.1 \\
\hline $2001-4000$ & 24 & 16.2 \\
\hline $4001-6000$ & 48 & 32.4 \\
\hline $6001-8000$ & 46 & 31.1 \\
\hline $\mathbf{8 0 0 1 - 1 0 0 0 0}$ & 10 & 6.8 \\
\hline$>10000$ & 05 & 3.4 \\
\hline Total & 148 & 100.0 \\
\hline
\end{tabular}

Source: Authors' fieldwork, 2020

\section{Educational qualifications of respondents}

Results further show that majority of respondents had primary education (58.1\%) while others had secondary education (22.3\%), no formal education (13.5\%) and tertiary education (6.1\%) (see Table 2 ). Education has been found to be a strong determinant of water accessibility [3]. Thus, investigations have shown that the higher the level of education, the tendency is the higher the level of consciousness of increased water use.

\section{Income distribution of the respondents}

Results on income distribution of the respondents reveals that majority of them earns $\$ 4001$ - $\$ 6000$ (32.4\%) monthly whereas, others earn $\$ 6001$ - $\$ 8000$ (31.1\%), \$2001 - \$4000 (16.2\%), < \$2000 (10.1\%), $\mathrm{N} 8001$ - $\$ 10000$ (6.8\%) and > $\$ 10,000$ (3.4\%) on monthly basis (see Table 3). According to Angoua et al. [6] and Gomez et al. [27], income level has a strong influence on domestic water demand. Consequently, income to a large extent determines the capacity of households to possess or construct water sources within their premises. However, findings in the study area show that most households depend on public or other free water facilities given the existing precarious poverty level. This is in consonance with what is experienced in other developing countries $(28,3)$. Households are thus, unable to access potable water sources within their house prem9ises. 
Ogunbode et al.

Table 5. Distribution of Sources of Water to Households

\begin{tabular}{ccc}
\hline Household Water Source & No of Responses & $\%$ \\
\hline Surface & 03 & 2.0 \\
\hline Groundwater & 143 & 96.6 \\
\hline Pipe-Borne & 02 & 1.4 \\
\hline Total & 148 & 100.0 \\
\hline Source: Authors' fieldwork, 2020 & &
\end{tabular}

Table 6. Ownership of the sources of water

\begin{tabular}{|c|c|c|c|c|c|}
\hline \multirow{2}{*}{\multicolumn{2}{|c|}{ S/No Water source }} & \multirow[t]{2}{*}{$\begin{array}{c}\text { Source } \\
\text { Type }\end{array}$} & \multicolumn{2}{|c|}{ Ownership } & \multirow[t]{2}{*}{ Total } \\
\hline & & & Public & Private & \\
\hline \multirow[t]{2}{*}{1.} & \multirow{2}{*}{ Groundwater } & Hand-dug & $\begin{array}{c}107 \\
(72.3 \%)\end{array}$ & $\begin{array}{c}15 \\
(10.1 \%)\end{array}$ & $\begin{array}{c}122 \\
(82.4 \%)\end{array}$ \\
\hline & & Borehole & $\begin{array}{c}19 \\
(12.8 \%)\end{array}$ & $\begin{array}{c}02 \\
(1.4 \%)\end{array}$ & $21(14.2 \%)$ \\
\hline \multirow[t]{2}{*}{2.} & Pipe-borne & $\begin{array}{l}\text { Stand } \\
\text { pipe }\end{array}$ & $\begin{array}{c}05 \\
(3.4 \%)\end{array}$ & - & 5 (3.4\%) \\
\hline & Total & & $\begin{array}{c}131 \\
(88.5 \%)\end{array}$ & $\begin{array}{c}17 \\
(11.5 \%)\end{array}$ & $\begin{array}{c}148 \\
(100 \%)\end{array}$ \\
\hline
\end{tabular}

Source: Authors' fieldwork, 2020

\section{Types of Ownership of Water Point Sources}

This study further evaluated the available point sources of water to households in the study area and by extension investigated the ownership structure and other implications of accessing such point sources. Findings are thus discussed as follows:

\section{Types of water sources to households}

The results as presented in Table 4 show that majority of respondents $(96.6 \%)$ sourced water for domestic uses from groundwater sources such as either hand-dug, boreholes and or motorized. Other respondents got water from surface point sources $(2.0 \%)$ and pipe-borne network (1.4\%). Though, there are visible signs of pipenetwork, investigation revealed that water hardly run from these taps. Consequently, most of respondents depend on ground sources for their domestic uses. This observation was similar to findings of Ishaku [28], Ogunbode and Ifabiyi [4].

There were attestations that surface water were most commonly used sources owing to their proximity to households and they were mainly used for washing gutters, floors and vehicles rather than for drinking, cooking or bathing. In addition, rainfall was not considered as a constant source of water to households because of its seasonality and its incidence may not necessarily coincide with domestic uses. Most respondents are even incapacitated to provide necessary facilities to encourage rainwater storage $[29,30]$.
Table 7. Time taken for fetching water in the study area

\begin{tabular}{ccc}
\hline Average Time Taken & No of Responses & $\%$ \\
\hline$<10$ mins & 62 & 41.9 \\
\hline 11-20mins & 24 & 16.2 \\
\hline 21-30mins & 35 & 23.7 \\
\hline$>30 m i n s$ & 27 & 18.2 \\
\hline Total & 148 & 100.0 \\
\hline
\end{tabular}

Source: Authors' fieldwork, 2020

\section{Ownership of water point sources}

The results as presented in Table 5 indicates that $85.1 \%$ of the water sources (mostly ground sources) were provided by the government or any of its agencies, $11.5 \%$ owned by private individuals within their premises while the remaining $3.4 \%$ of the respondents (mostly living close to Iwo Water Works) obtain their water from the available pipe-borne water network. These results corroborate the findings of Ogunbode and Ifabiyi [24] where it was found that efforts of government or any of its agencies are very salient to the availability of water in Nigeria and other West African countries. The dominance of the use of groundwater sources in the study area reflects the shirking of responsibilities by the government which should have provided and emphasized on the use pipeborne water network- an acclaimed to be the safest source for human consumption and other domestic purposes [3].

\section{Time taken for fetching water in the study area}

The average time taken by respondents to fetch water for their domestic uses was presented in Table 6 . Results show that majority of respondents (41.9) spend $<10$ minutes to available source of water in proximity to their premises. Other respondents spend between 21 to 30 minutes $(23.7 \%),>30$ minutes $(18.2 \%)$ and 11 to 20 minutes $(16.2 \%)$ to get water to their respective homes for domestic purposes. This observation was equally corroborated by Graham et al. [23]. Though, about $81.8 \%$ of households in the study area get water within the United Nations recommended benchmarked time required to get water for home uses, the emphasis is with households (59.1\%) having to travel far beyond threshold distances to get water at sources not safe and sufficient enough for their daily need because they do not have water point sources within their premises (see also Diwakar [31]. This is further worsened at this contemporary time when the spread of COVID-19 through social contacts needs to be curtailed. 
Table 8. Ease of Accessing Water during COVID-19 Lockdown

\begin{tabular}{cccc}
\hline S/No & $\begin{array}{c}\text { Respondents' } \\
\text { Remark }\end{array}$ & $\begin{array}{c}\text { No of } \\
\text { Category }\end{array}$ & \% of category \\
\hline 1. & Easy & 69 & $46.6 \%$ \\
\hline 2. & Difficult & 43 & $29.1 \%$ \\
\hline 3 & Very Difficult & 36 & $24.3 \%$ \\
\hline Total & & 148 & 100 \\
\hline
\end{tabular}

Source: Authors' fieldwork

Table 9. Strategies for obtaining potable water during the global COVID-19 lockdown

\begin{tabular}{ccc}
\hline Strategy & $\begin{array}{c}\text { No of } \\
\text { Responses }\end{array}$ & $\%$ \\
\hline Fetching in the night & 18 & 12.2 \\
\hline Rotation among homes & 24 & 16.2 \\
\hline Surface sources & 13 & 8.8 \\
\hline Water Purchase/Hiring fetchers & 02 & 1.4 \\
\hline Public facility & 62 & 41.9 \\
\hline Rainfall Harvesting & 04 & 2.7 \\
\hline Increased storage facility & 08 & 5.4 \\
\hline Locking up (gate or the water point) & 17 & 11.4 \\
\hline $\begin{array}{c}\text { Lackadaisical attitude about social } \\
\text { distancing }\end{array}$ & 25 & 16.9 \\
\hline Water reuse/recycling & 12 & 8.1 \\
\hline $\begin{array}{c}\text { Minimizing the use of water-using } \\
\text { facilities }\end{array}$ & 12 & 8.1 \\
\hline Source: Authors' fieldwork, 2020 & &
\end{tabular}

\section{Ease of accessing water during COVID-19 lockdown}

The result as presented in Table 7 shows that $46.6 \%$ claimed that getting water for their daily domestic use during the pandemic lockdown is easy. Other respondents have claimed that it is difficult $(29.1 \%)$ and a very difficult task (24.3\%). In the event that households have to travel which, most times involved trekking beyond threshold distances to access water point sources, their susceptibility to impacts are further exacerbated and they had been forced to resort to unhealthy use and reuse of available sources of water near them. These discoveries were also corroborated by Cooper [9] and WHO [10]. By observation, the following factors have contributed to this experience: Firstly, the source is not within their premises; secondly, the public facility in their community could not be fueled and even faulty power generators which could not be repaired as a result of the COVID-19 lockdown; thirdly, limited storage facilities; fourthly, difficulty in mobilizing community members for discussion on water issues; and lastly, vehicular movement prohibition.

\section{Strategies for obtaining potable water during the global lockdown}

Table 8 shows that each household adopted different strategies to ensure access to potable water during the lockdown. While $12.2 \%$ adopted night fetching, $16.2 \%$ indicated that the fetching was done on rotational basis at least to avoid any form of convergence at water points. Also, $8.8 \%$ claimed that they resorted to surface source alternative for certain water-based activity like cloth washing, vehicles washing, among others to conserve the available potable water. Apart from these, $1.4 \%$ opted for water purchase or hiring fetchers who will go and fetch for them at a cost. This is done at least to prevent them from going to water points where a lot of people could converge in search of water. In another instance, $41.9 \%$ of the respondents claimed that they resorted to public facilities in their neighborhood when their respective privately-owned sources located within the owners' respective houses' premise could not be accessible; $2.7 \%$ also revealed that rain water was an added advantage and so has contributed to their accessibility to water for their home use, being the rainy period while $11.4 \%$ took to locking up their gates or water source to avoid outsiders that could be suspected carriers of COVID-19, and so have unhindered access. Thus, a lot of people that used to fetch within these compounds/premises were denied further access to water as a result of COVID-19 pandemic; $5.4 \%$ of the respondents considered conversion of some other containers, previously used for other purposes other than water storage to water containers to improve on water storage capacities; $16.9 \%$ were not bothered about the disease for lack of any other option of getting water, $8.1 \%$ chose practice of water recycling and rationing to ensure water availability for various home uses. This category opted for skipping baths and wearing clothes that keep dirt towards ensuring water access during the lockdown and $8.1 \%$ also stated that water closets in their homes are occasionally neglected in favor of pit toilet or use of surrounding bush for defecation to conserve water. Cooper's [32] observation also supported this fact that various strategies were adopted by people, especially in the developing areas to have access to water for domestic uses. In the same vein, Anim and Ofori-Asenso [33], and Boretti [34] lamented that COVID-19-induced movement restrictions among other challenges posed by the pandemic may exacerbate poverty level which may translate in lack of food and water potentially, the situation that may be much more worrying than the virus spreading. 
Ogunbode et al.

Table 10. Respondents' views on the impact of COVID19 pandemic on the access to water

\begin{tabular}{ccc}
\hline Option & No of responses & $\%$ \\
\hline Agree & 31 & 20.9 \\
\hline Strongly Agree & 85 & 57.4 \\
\hline Disagree & 13 & 8.8 \\
\hline Strongly Disagree & 07 & 4.7 \\
\hline No response & 02 & 1.4 \\
\hline Total & 148 & 100.0
\end{tabular}

Source: Authors' fieldwork, 2020

\section{Respondents' views on the impact of COVID- 19 pandemic on the access to water}

The results presented in Table 9 show that 116 respondents (78.3\%) either agree or strongly agree that the COVID-19 pandemic and its consequential global lockdown has exacerbated impacts on their accessibility to their water source or sources. This finding corroborated the observation of Anim and OforiAsenso [33], and Tortajada and Biswas [35] that lamented that the pandemic has caused deterioration in the living conditions of millions of people both in developed, even in US and developing countries, the relief time of which is still uncertain. However, 20 respondents $(13.5 \%)$ showed their disagreement that the situation had any impact on their access to improved water sources, possibly, they form the category of respondents that claim ownership of water sources because it is located in their respective premises.

\section{CONCLUSION AND RECOMMENDATIONS}

An assessment has been made of the impact of the ravaging COVID-19 on the sustainability of the success recorded by the United Nations through MDGs on accessibility to improved water globally and in developing nations in particular. The findings showed that the pandemic restricted respondents' access to potable water. Two of the ways of preventing the infection of COVID-19, according to World Health Organization [10] is avoiding crowding and also personal hygiene among others. The fulfillment of the first condition is dicey especially in Africa with the level of poverty (See [36-39]) and poor access to portable water (See also [1]). The few water points, mostly ground sources, are often crowded. The implications of this prevailing situation is that there will be enough room for the spread of the disease, the situation that spell doom for developing nations and the global community. This is to buttress the view of Cilliers et al. $[40,41]$ that COVID-19 may constrain Africa's progress towards attaining the 2030 SDGs. Today, the report so far indicates that there is increase in the number infected globally and particularly in Africa, while also the number of deaths is still on the rise [10].

In view of these findings, the SDG target on water accessibility (as entrenched in Goal 6): Ensure availability and sustainable management of water and sanitation for all) is being recommended for review to accommodate not only accessibility to water but also emphasizing on "each household unit each tap" as part of the strategies to achieving this goal (see [42]).

Enormous surface water resources in most of these countries should be optimally exploited for the purpose of pipe borne water network which is even more environmental-friendly. The target review in this direction, though may require more commitment in the areas of capital outlay especially, is expected to achieve freer and better equitable access to portable water; drastic reduction or total elimination of crowding at water points; minimizing infection of COVID-19 through crowding at water points; improved household sanitation and living condition; and minimizing the potential geological disturbance which may be associated with unabated underground sources exploitation. Instituting relevant and binding treaties and agreements will enhance implementation, especially in the developing nations.

\section{ACKNOWLEDGEMENT}

The authors acknowledge the contributions of Miss Grace Adeola (Gracey) and Victor Oyedeji (Vicky) both of Obafemi Awolowo University, Ile-Ife, Nigeria in the collection and analysis of the data, typing and proofreading of the manuscript.

Conflict of Interest: None to Declare

Source of funding: No funding

\section{REFERENCES}

1. United Nations. Transforming our world: The 2030 Agenda for Sustainable Development 2019 CA/RES/70/1. Available at: http: / / www.sustainabledevelopment.un.org

2. United Nations. Millennium Development Goal Report: 2015 Time for Global Action for People and Planet, 2015, New York. 
3. Ifabiyi IP, Ogunbode TO. Determinants of domestic water consumption in a growing urban centre in Osun State, Nigeria. Afrcan J. Envir. Sci. Tech., 2014; 8(4): 247-55. doi: 10.5897/AJEST2013.1627.

4. Ogunbode TO, Ifabiyi IP. Applicaion of Water Poverty Index (WPI) in assessing water accessibility in the rural suburbs of Ogbomoso Zone of Oyo State, Nigeria. Asian J. Envir. Ecol., 2017b; 3(2): 1-9. doi: 10.9734/AJEE/2017/34095.

5. Ainuson KG. Urban Water Politics and Water Security in Disadvantaged Urban Communities in Ghana. African Studies Quarterly, 2010; 11(4): 5982.

6. International Bank for Reconstruction and Development World Bank. A Wake Up Call: Nigeria Water Supply, Sanitation and Hygiene Poverty Diagnostic. WASH Poverty Diagnostic Series. 2017, World Bank, Washington, D.C.

7. Angoua ELE, Dongo K, Templeton MR, Ziusstag J, Bonfoh B. Barriers to a access improved water and sanitation in poor peri-urban settlements of Abidjan, Cote d'Ivoire, PLoS ONE, 2018; 13(8): eo202928. doi: 10.1371/journal.pone.0202928.

8. WaterAid. Equal to the task: Financing for a state of emergency in Nigeria's water, sanitation and hygiene sector: Case study. Development Initiatives of WaterAid, Nigeria and United Kingdom. 2019.

9. Cooper R. Water for the urban poor and COVID-19 crisis. Helpdesk Report 826, Brighton, UK: Institute of Development Studies, 2020.

10. WHO and UNICEF. Water, Sanitation, Hygiene and Waste Management for the COVID-19 virus: Interim guidance. WHO/2019-nCoV/IPC_WASH/2020.2., 2020.

11. NCDC. An update of COVID-19 outbreak in Nigeria Abuja, Nigeria 2020. Available at: http: //covid19.ncdc.gov.ng/index.html (Accessed: 7 October 2020).

12. United Nations University- INWEH. Global Water Crisis: The Facts, UNU-INWEH Canada. 2017.

13. Africa Public Health Info. 2020. (Accessed: 16 June, 2020).

14. Mallapaty S. How sewage could reveal true scale of coronavirus outbreak. Nature, 2020; 580: 176-7. doi: 10.1038/d41586-020-00973-x.
15. Rimoldi SG, Stefani F, Gigantiello A, Polesello S, Comandatore F. Presence and vitality of SARS-CoV2 virus in wastewaters and rivers. 2020. doi: 10.1101/2020.05.01.20086009.

16. Wurtzer S, Marechal V, Mouchel JM, Moulin L. Time course quantitative detection of SARS-CoV-2 in Parisian wastewaters correlates with COVID-19 confirmed cases. $2020 . \quad$ doi: 10.1101/2020.04.12.20062679.

17. Ogunbode TO, Akintunde EA, Akinola OT. Assessment of underground water quality and pollution sources apportionment in a growing Urban centre In Osun State South Western Nigeria. European J. Geography, 2016; 7(3): 71-85.

18. Adeyemi O, Adeyeye O, Durowoju O. Groundwater: quality levels and human exposure, SW, Nigeria. J. Environmental Geography, 2017; 10(1-2): 23-9. doi: 10.1515/jengeo-2017-0003.

19. Fadipe 00 , Oladepo KT. Temporal variation of groundwater resources in llesa West Local Government, Osun State Nigeria. Nigerian J. Technology, 2020; 39(1): 315-24. doi: 10.4314/njt.v39i1.35.

20. National Population Commission. Federal Republic of Nigeria 2006 Population Census Statistics. 2006.

21. Acey C. Gender and community mobilisation for urban water infrastructure investment in southern Nigeria. Gender and Development, 2010; 18(1): 1126. doi: $10.1080 / 13552071003599970$.

22. Demie G, Bekele M, Seyoum B. Water accessibility impact on girl and women's participation in education and other development activities: the case of Wuchale and Jidda Woreda, Ethiopia. Environ Syst Res., 2016; 5(11). doi: 10.1186/s40068-016-0061-6.

23. Graham JP, Hirai M, Kim S. S. An Analysis of Water Collection Labor among Women and Children in 24 Sub-Saharan African Countries. PLoS ONE, 2016; 11(6): e0155981. doi: 10.1371/journal.pone. 0155981.

24. Ogunbode TO, Ifabiyi IP. Domestic Water Utilization and its determinants in the rural areas of Oyo state, Nigeria using multivariate analysis. Asian Research J. Arts Soc. Sci., 2017a; 3(3): 1-13. doi: 10.9734/ARJASS/2017/34096. 
Ogunbode et al.

25. Sülün EE. Women, Water Resource Management, and Sustainable Development: The Turkey-North Cyprus Water Pipeline Project. Resources, 2018; 7, 50. doi: $10.3390 /$ resources 7030050 .

26. Ibaishwa RL, Abaagu A. Gender Access to Rural Water Supply, Sanitation and Hygiene in Rural Communities in Benue State, Nigeria. PAUWES Research-2-Practice Forum 2018. doi: $10.2139 /$ ssrn. 3210631.

27. Gomez M, Perdiguero J, Sanz A. Socioeconomic factors affecting water access in rural areas of low and middle income countries. Water, 2019; 11(2): 202. doi: $10.3390 / 1011020202$.

28. Ishaku HT. Water Supply dilemma in Nigerian rural communities: Looking towards the sky for an answer. J. Wat. Resour. Protec., 2011; 03(08): 598-606. doi: 10.4236/jwarp.2011.38069.

29. Kiggundu N, Wanyama J, Mfitumukiza D, Twinomuhangi R, Barasa B, Katimbo A, Kyazze FB. Rainwater harvesting knowledge and practice for agricultural production in a changing climate: A Review from Uganda's Perspective. AgricEngInt: CIGR J., 2018; 20(2): 19-36.

30. Al-Batsh N, Al-Khatib IA, Ghannam S, Anayah F, Odeh S, Hanbali $G$, Khalaf $B$, van der Valk $M$. Assessment of rainwater harvesting systems in poor rural communities: A case study from Yata Area, Palestine. Water, 2019; 11: 585. doi: 10.3390/w11030586.

31. Diwakar V. From Pandemics to Poverty: Hotspots of vulnerability in times of crisis. Emerging Analysis andldeas, p17, 2020. Available at: https: / /www.odi.org/files/resource/documents/ coronavirus_from_pandemics_to_poverty.pdf

32. Cooper R. Water Security beyond Covid-19. Brighton, UK: Institute of Development Studies, 2020b.
33. Anim DO, Ofori-Asenso R. Water scarcity and COVID-19 in sub-Saharan Africa. The Journal of infection, 2020; 81(2): e108-e109. doi: 10.1016/j.jinf.2020.05.032.

34. Boretti A. Covid-19 pandemic as a further driver of water scarcity in Africa. GeoJournal, 2020, 1-28. Advance online publication. doi: 10.1007/s10708020-10280-7.

35. Tortajada C, Biswas AK. COVID-19 heightens water problems around the world. Water International, 2020; 45(5). doi: $10.1080 / 02508060.2020 .1790133$.

36. Alkire S, Housseini B. Multidimensional poverty in sub-Saharan Africa: Levels and Trends. Oxford Poverty and Human Development Initiatives (OPHI), 2014, Working Paper No. 8, Oxford University.

37. Institute for Security Studies. Reasonable goals for reducing poverty in Africa: Targets for the post2015 MDGs and Agenda 2063: African Future Paper 13. 2015, Frederick S. Pardee Centre for International Futures.

38. World Bank Group. Poverty in a rising Africa- An Overview. Africa Poverty Report. International Bank for Reconstruction and Development/The World Bank., 2016.

39. UNU-WIDER. Development and poverty in subSaharan Africa. WIDER Working Paper 2017/169. United Nations University World Institute for Development Economics Research. 2017. doi: 10.3518/UNU-WIDER/2017/395-0.

40. Cilliers J, Oosthuisen M, Alexander K, Kwasi S, Pooe TK, Yeboua K, Moyer JD. Impact of COVID-19 in Africa A scenario analysis to 2030. 2020; SSRN Electronic Journal; doi: 10.2139/ssrn.3660866

41. Sridha MKC. COVID-19 and the Environment. Afr. J. Envir. Health, 2020; 7(1-9).

42. www.who.int/water_sanitation_health/monitorin g/water.pdf 